\title{
Biotic and abiotic factors of bactericidal properties variability of ruminant saliva
}

\author{
Rustam Y. Gilmutdinov ${ }^{1}$, Gennady N. Spiridonov ${ }^{2}$, Guzel G. Shalamova ${ }^{1,{ }^{*}}$ and Ekaterina S. Pokrovskaya ${ }^{2}$ \\ ${ }^{1}$ Kazan State Academy of Veterinary Medicine named after N.E. Bauman, Kazan, 420029, Russia \\ ${ }^{2}$ Federal Center for Toxicological, Radiation and Biological Safety, Scientific town-2, Kazan, 420075, Russia
}

\begin{abstract}
The microflora of the oral cavity of domestic ruminants, presented by transitive gram-negative species of bacteria (cocci and sticks) in cows, transient and obligate gram-positive (usually cocci) bacteria in sheep was studied. The lowest contamination of the sheep mouth mucosa was observed in autumn, and the largest in summer. Seasonal features of bactericidal activity of saliva and its main components (lysozyme, properdin and complement system) are shown. Differences of the above indicators in cows and sheep are considered. Low activity is typical for saliva complement system in ruminants in general and sheep in particular. Lysozyme activity and properdin content are maximum in cows and sheep in summer, with elongation towards autumn (exception - lysozyme activity in sheep extends in spring).
\end{abstract}

\section{Introduction}

The oral microflora is extremely diverse and includes bacteria, actinomycetes, fungi, protozoa, spirochetes, rickettsia, viruses. Normally, the microbial composition of the mouth is dominated by bacteria, while viruses and protozoa are represented by a significantly smaller number of species.

The vast majority of such microorganisms are saprofite commentals, they do not cause visible harm to the host. The term "normal microflora" combines microorganisms more or less often isolated from a healthy organism.

Quite often it is impossible to draw a clear boundary between saprophytes and pathogens that are part of normal microflora. A quite wide range of factors of nonspecific protection, including immune protection, regulates the microbial balance of the oral cavity. Thus, acids formed as a result of the enzymatic activity of streptococci inhibit the growth of some rotten microorganisms that get into the oral cavity from the environment.

In modern veterinary medicine, the study of humoral non-specific immunity factors is generally limited to the use of blood serum. Meanwhile, saliva opportunities attract increasing interest among human medicine specialists as an alternative, especially during express diagnostics $[1,2]$.

Humoral non-specific factors of immunity, including saliva, are provided primarily by lysozyme, complement, properdin, and the indicator of bactericidal activity is widely used as their integral characteristic [3].

Saliva is a biological body fluid that is constantly present in the oral cavity. Saliva participates in the protection of dental surface and oral mucosa against bacterial effects, performs bactericidal function. It is a natural factor, an exchange medium into which substances from blood serum enter, thus maintaining homeostasis. Today, saliva is under-investigated and still undervalued.

As the body's biological environment, saliva has the right to exist as an object for rapid diagnosis. Compared to blood, it more dynamically reflects daily changes in the body [4] and plays an important role in providing oral homeostasis. It contains a large number of proteins having antimicrobial properties.

In recent years, the study of saliva has been given special attention as it has been found to play an important role in maintaining local oral immunity [5-8].

In order to carry out the immunological monitoring of the population, it is necessary to use informative and non-invasive methods of examination, so the use of saliva, as one of the readily available biological fluids of the body, is a very promising method.

The bactericidal properties of saliva are determined and defined by the qualitative and quantitative state of oral microflora and it is necessary to have a clear understanding of the "norm" for its proper evaluation.

We have studied the influence of the year season on the quantitative-species spectrum of oral microflora of cattle and small cattle, as well as physical-chemicalbiological methodological features of humoral nonspecific immunity factors.

\section{Materials and methods}

The studies were conducted on clinically healthy blackand-white cows aged 4-6 years and Precoce sheep aged 2 years. Saliva was collected after activation of its

* Corresponding author: guzel471979@mail.ru 
secretion with $1 \%$ pilocarpine hydrochloride solution at $2.5 \mathrm{ml}$ per sheep and $15 \mathrm{ml}$ per cow.

The microbial landscape of the oral cavity was determined using Himedia bacteriological kit (India) and various bacteriological nutrient media ( $5 \%$ blood - to estimate total microbial contamination; colombian and yellow-salt agars - to count staphylococcus and other bacteria; vegetable-dairy media - to count lactobacteria, Endo - to count intestinal microflora and Saburo - to count Candida fungi; sugar broth - to cultivate a wide range of microorganisms). The test material was taken from the area of mucous membranes and the tongue surface with an area of $1 \mathrm{~cm}^{2}$. Bacterial inoculations were incubated in a thermostat for 24 hours, inoculation for Candida fungi - 5 days. The defined strains of microorganisms were stained by Gram and identified on the basis of morphological, cultural and biochemical features.

E. coli (gram-negative microorganism) and B. subtilis, M. luteus (gram-positive microorganisms) cultures were used to determine bactericidal activity by Smyrnova O.V., Kuzmina T.A. [9] in Malev A.A. [10] modification and saliva lysozyme.

Complementary activity was determined by Resnikova L.C. (1967), assessing \% hemolysis.

Lysozyme activity was evaluated by the method of Kisel S.S. [11] based on the M. luteuspode enlightenment by the influence of lysozyme contained in saliva.

The properdin level was determined by Tomilka G.S., Starostina I.S. [12]. The zymosan preparation from Fluka (Switzerland) was thus used; dry bovine albumin (BelNIIEM, Belarus); Buffers: veronal-medina, trisic, glycine.

The obtained experimental data were processed by variation statistics methods [13], which included the calculation of arithmetic mean value, arithmetic mean error, difference validity criterion and influence force. The influence force of various factors was studied by variance analysis with application package for personal computer STATAN-96.

The variance analysis allows for the identification of dependencies in experimental data by examining the significance of differences in mean values. Unlike the tcriterion, it allows the average values of three or more groups to be compared. The essence of the variance analysis is to study the effect of one or more independent variables, commonly referred to as factors, on a dependent variable.

\section{Results and discussion}

The oral cavity of cows showed to be dominated by transitive gram-negative sticks of the Enterobacteriaceae family. In summer, Candida obligate fungi are added to them. In autumn, the oral landscape was also presented by transitive gram-negative streptococci, and in $25 \%$ of cases there was no etiologically significant growth of microorganisms. In winter and spring these figures were distributed equally (50:50), with only that feature that transitive gram-positive cocci were also present in a mouth in spring.

The oral microbial landscape of sheep during summer was dominated by transitive gram-negative sticks and gram-positive cocci (both transitive and obligate).

In autumn, in $100 \%$ of cases in the mouth mucosa of sheep there was no etiologically significant growth of microorganisms. In winter, the microflora was represented by gram-positive cocci, $50 \%$ of which were Stomatococcuscusmucilaginosis. In spring, transitive gram-positive staphylococci were often identified. In $75 \%$ of cases, Staplylococcuslentus was found. Thus, unlike cows, the mouth microflora of sheep was mainly represented by gram-positive cocci. The greatest contamination by transitive microbes was observed in the summer-autumn period.

Many researchers [14, 15 et al.) noted seasonal dependence of natural animal resistance.

In our research we observed seasonal variability of bactericidal, lysozyme and complementary activity, as well as the content of properdin saliva in ruminants (Table 1). Regardless of the animal species and test microbe used, they had the maximum values in summer (the exception being B. subtilis in cows) and the minimum values in winter-spring (the exception being $\mathrm{B}$. subtilis in cows and M. luteus in sheep).

Table 1. Seasonal dependence of bactericidal and lysozyme activity, content of properdin saliva of ruminants

\begin{tabular}{|c|c|c|c|c|}
\hline \multirow{2}{*}{$\begin{array}{l}\text { Animal } \\
\text { species }\end{array}$} & \multirow{2}{*}{\multicolumn{2}{|c|}{$\begin{array}{l}\text { Non-specific } \\
\text { immune factors }\end{array}$}} & \multicolumn{2}{|c|}{ Season } \\
\hline & & & $\begin{array}{c}\text { Summer- } \\
\text { autumn }\end{array}$ & $\begin{array}{l}\text { Winter- } \\
\text { spring }\end{array}$ \\
\hline \multirow{5}{*}{ Cow } & \multicolumn{2}{|c|}{ Lysozyme, \% } & $40.3+0.8$ & $37.3+0.7$ \\
\hline & \multicolumn{2}{|c|}{ Properdin, $\mu \mathrm{g} / \mathrm{ml}$} & $133.0 \pm 7.4^{*}$ & $110.0 \pm 7.0$ \\
\hline & \multirow{3}{*}{$\begin{array}{c}\text { Saliva } \\
\text { bactericid } \\
\text { al activity }\end{array}$} & E. coli & $51.5+1.3^{* *}$ & $58.1+0.9$ \\
\hline & & B. subtilis & $57.5 \pm 1.0 *$ & $64.8 \pm 1.1$ \\
\hline & & M. luteus & $62.8 \pm 1.1 * *$ & $68.2 \pm 1.2$ \\
\hline \multirow{5}{*}{ Sheep } & \multicolumn{2}{|c|}{ Lysozyme, \% } & $29.1+0.8^{* *}$ & $26.6 \pm 1.0$ \\
\hline & \multicolumn{2}{|c|}{ Properdin, $\mu \mathrm{g} / \mathrm{ml}$} & $82.2 \pm 6.0 * *$ & $66.0 \pm 5.5$ \\
\hline & \multirow{3}{*}{$\begin{array}{c}\text { Saliva } \\
\text { bactericid } \\
\text { al activity }\end{array}$} & E. coli & $45.1+1.0 * *$ & $50.4 \pm 1.0$ \\
\hline & & B. subtilis & $52.9 \pm 1.1 * *$ & $58.5 \pm 0.9$ \\
\hline & & M. luteus & $58 .+1.0 *$ & $61.7 \pm 1.6$ \\
\hline
\end{tabular}

Note: $*$ and $* *$-difference confidence levels with respect to winter-spring (p), $\leq 0.001$ and $\leq 0.0$ respectively.

Besides, the bactericidal activity of ruminant saliva relative to gram-negative bacteria (E. coli) in all cases, regardless of animal species and season of the year, was less than that of B. subtilis and M. luteus, among which it was higher in M. luteus.

Bactericidal activity is an integral indicator characterizing humoral factors of non-specific immunological resistance of animals. In the majority of publications this indicator is determined in blood serum, and with respect to saliva there are only some works carried out in humans.

The value of bactericidal activity of saliva was also influenced by the duration of sample incubation. Depending on the concentration of test microorganisms, the saliva bactericidal activity of cows and sheep had both positive and negative values. The optimal concentration, according to our data, is E. coli and M. 
luteus amounting to $1 \mu \mathrm{g} / \mathrm{ml}$, and B. subtilis amounting to $30 \mu \mathrm{g} / \mathrm{ml}$.

Lysozyme (muramidase) is a non-specific protection factor of the body, a mucolytic enzyme that hydrolyses glycoside bonds in glycosaminoglycans and proteoglycans. The natural substrate of lysozyme is the polysaccharides of the bacteria cell wall. By cleaving the polysaccharides of plasma membranes of the bacterial cell, lysozyme is one of the mechanisms of protection against pathogenic gram-positive bacteria that contaminate the mucosa of the oral cavity.

Properdin plays a very important biological role. It is believed that the body's resistance to a number of diseases depends on its content. Properdin is capable of destroying certain types of bacteria and viruses. It is a positive regulatory component of alternative complement activation pathway, acting as a $\mathrm{C} 3 / \mathrm{C} 5$ convertase stabilizer on the surface of the bacterial cell.

Both lysozyme activity and properdin saliva content in cows and sheep were higher during the summerautumn period. The maximum (20 \%) seasonal differences were observed in the properdin content of sheep; in all other cases the differences did not exceed 7-8\%.

The complement system is a powerful stimulant of bacteria lysis circulating in the blood that is present in the oral cavity of animals and humans and takes a key part in the body protection from infections. Complementary activity of saliva in ruminants in general was low and in cows exceeded that in sheep by $16.3 \%$. Presumably, this fact explains low levels of phagocytosis in the oral cavity [16], since there is a direct functional link between these characteristics.

In general, it is believed that the components of the bactericidal saliva system are closely related, and the change of activity or content of one of them causes the change of the others.

When analyzing the obtained results, it should be taken into account that the total amount and composition of saliva released by ruminants to a large extent depends on the rumen motility, the intensity of rumination, the chemical composition and the physical form of the feed. Thus, when eating silage and grass, saliva is released less than when eating hay.

The variance analysis performed in cows and sheep for all considered factors confirmed that the null hypothesis of random difference of non-specific immunological resistance factors is rejected.

The contribution of each above discussed factor to the formation of bactericidal activity of saliva was reliable and made $11-35 \%$ in cows (Table 2) and 17-36 $\%$ in sheep respectively (Table 3 ).

Since the indicator of bactericidal activity of saliva proved to be sufficiently labile, it was important to assess the degree of influence of the type of test microorganism on the variability of this indicator. For this purpose, we examined 3 gradations (E. coli, B. subtilis and M. luteus) through the variance analysis.
Table 2. Influence force of various factors on bactericidal activity of saliva in cows

\begin{tabular}{|c|c|c|c|c|}
\hline Factors & $\begin{array}{c}\text { Influence } \\
\text { force, \% }\end{array}$ & $\begin{array}{c}\text { Fisher's } \\
\text { ratio test }\end{array}$ & $\begin{array}{c}\text { Degree of } \\
\text { freedom, k1 }\end{array}$ & $\begin{array}{c}\text { Degree of } \\
\text { freedom, k2 }\end{array}$ \\
\hline Season & 35 & 18 & 9 & 300 \\
\hline $\begin{array}{c}\text { Test } \\
\text { microorganis } \\
\text { m }\end{array}$ & 21 & 33 & 4 & 485 \\
\hline $\begin{array}{c}\text { Complement } \\
\text { activity }\end{array}$ & 33 & 2.9 & 4 & 23 \\
\hline $\begin{array}{c}\text { Lysozyme } \\
\text { activity }\end{array}$ & 31 & 12.5 & 1 & 23 \\
\hline $\begin{array}{c}\text { Properdin } \\
\text { content }\end{array}$ & 11 & 4.6 & 1 & 23 \\
\hline
\end{tabular}

Table 3. Influence force of various factors on bactericidal activity of saliva in sheep

\begin{tabular}{|c|c|c|c|c|}
\hline Factors & $\begin{array}{c}\text { Influence } \\
\text { force, } \\
\text { \% }\end{array}$ & $\begin{array}{c}\text { Fisher's } \\
\text { ratio test }\end{array}$ & $\begin{array}{c}\text { Degree of } \\
\text { freedom, } \\
\mathbf{k 1}\end{array}$ & $\begin{array}{c}\text { Degree of } \\
\text { freedom, } \\
\text { k2 }\end{array}$ \\
\hline Season & 25 & 8 & 6 & 100 \\
\hline $\begin{array}{c}\text { Test } \\
\text { microorgani } \\
\text { sm }\end{array}$ & 13 & 23 & 7 & 285 \\
\hline $\begin{array}{c}\text { Complemen } \\
\text { t activity }\end{array}$ & 36 & 1.7 & 4 & 29 \\
\hline $\begin{array}{c}\text { Lysozyme } \\
\text { activity }\end{array}$ & 29 & 9.5 & 2 & 13 \\
\hline $\begin{array}{c}\text { Properdin } \\
\text { content }\end{array}$ & 17 & 5.9 & 1 & 33 \\
\hline
\end{tabular}

The variance analysis of this combination of test microorganism species proved that when similar species (e.g. gram-positive B. subtilis and M. luteus) were analyzed, the effect of this factor was insignificant: 2.7 for cows and $3.3 \%$ for sheep, but reliable; in the analysis of all species, taking into account gram-negative E. coli, the influence force of test microorganism species increases to 21 and $13 \%$, respectively.

The differences in bactericidal activity of saliva are valid in all combinations with $E$. coli, as well as in the pair B. subtilis and M. luteus. Thus, the effect of test microorganism species (even slightly different) on the bactericidal activity of saliva is beyond any doubt.

A single factor variance analysis showed that the effect of lysozyme activity on the formation of bactericidal activity index of saliva is significant and makes $31 \%$ for cows and $36 \%$ for sheep; the force of the properdin content is also valid and makes 11 and $17 \%$, respectively.

Thus, the use of variance analysis revealed a complex of factors on which the bactericidal activity of saliva depends.

It turned out that in cows the main factors determining statistically significant differences in bactericidal activity of saliva are in the order of reduction of the influence force season, complementary activity, lysozyme activity, type of test microorganism and properdin content.

In sheep, this order is slightly different and is as follows: lysozyme activity, complementary activity, 
season of the year, properdin content and type of test microorganism.

\section{Conclusion}

The oral microflora of cows is mainly represented by transitive gram-negative species of bacteria (cocci and sticks), and that of sheep - by gram-positive (usually cocci). The lowest contamination of the sheep's mouth mucosa was observed in autumn, and the largest in summer.

The bactericidal activity of saliva of ruminants, regardless of the species and test microbe used, had the maximum values in summer (exception - B. subtilis in cows) and the minimum - winter-spring (exception - B. subtilis in cows and M. luteus in sheep).

In cows, the bactericidal activity of saliva is mainly directed towards gram-negative, and in sheep - towards gram-positive microorganisms (cocci). In cows it is more determined by complementary and lysozyme activity than in sheep.

For the complement system, the saliva of ruminants in general and sheep in particular is characterized by low activity.

Lysozyme activity and properdin content will increase the maximum values in cows and sheep in summer, with elongation towards autumn (exception lysozyme activity in sheep extends in spring).

In cows, the main factors determining the bactericidal activity of saliva are, in order of reduction of the influence force, season of the year, complementary activity, lysozyme activity, type of test microorganism and properdin content.

In sheep, this order is slightly different and is as follows: lysozyme activity, complementary activity, season of the year, properdin content and type of test microorganism.

\section{References}

1. A.S. Budikhina, Evaluation of bactericidal activity of biological fluids in normal state and in pathology by laser flow cytometry, $\mathrm{PhD}$ Dissertation thesis (Moscow, 2007), 19 p.

2. A.G. Karslieva, D.A. Dominyuk, Assessment of mixed saliva bactericidal activity in children at early stages of instrument treatment using base materials, in: Thesis XIII Int. Med. Congr. Euromedic (Hannover, 2014), pp. 40-41
3. M. Ahmad, M. Piludu, F. Oppenheim et al., Immunocytochemical localization of histatins in human salivary glands, J. Histochem. Cytochem. 52, 361-370 (2004)

4. L. Liliam, Xerostomie et implications odonto stomatologique, These pour obtention de doct. (France, Nancy, 2011), 194 p.

5. O.A. Gavrilova, Local immunity of the oral cavity in schoolchildren with digestive pathology, Dentistry 5, 71-73 (2009)

6. O.A. Naumenko, E.V. Sablina, O.Ya. Sokolova, E.A. Kostenetskaya, Method of assessing local nonspecific immunity of human oral cavity by rhodanides content in saliva, J. of Orenburg State Univer. 1(176) (2015)

7. I.V. Papilko, G.V. Nikulin, Daily dynamics of immunological indices of oral fluid, in: Mater. of the satellite symp. of the 20th Congr. of physiology. of Russ. Ecology and Health (RUDN, Moscow, 2007), pp. 126.

8. I.V. Radysh, V.I. Gorshin, I.V. Papilko et al., Study of immunological indices of oral fluid at different times of day, J. of RUDN 6, 75-79 (2007)

9. O.V. Smirnova, T.A. Kuzmina, Determination of bactericidal activity of blood serum by photonephelometry, ZMEI 4, 8-11 (1966)

10. A.A. Malev, Bactiricidal activity of blood of various types of animals, its diagnostic significance, $\mathrm{PhD}$ Dissertation (Kazan, 2009), 131 p.

11. Kisel, S.S. Improved turbidimetric procedure for determining lysozyme activity, Healthcare of Belarus 5, 36-38 (1972)

12. G.S. Tomilka, I.S. Starostina, Modification of blood serum properdin method, Lab. Studies 2, 126-127 (1986)

13. S.N. Gashev, Statistical Analysis for Biologists (TumSU Univer., Tyumen, 1998), 51 p.

14. E.A. Duvanova, Formation of natural resistance and productivity of sheep of various genotypes, $\mathrm{PhD}$ Dissertation (Voronezh, 2006), $141 \mathrm{p}$.

15. A.R. Aglulina, V.L. Leutsky, Age and seasonal variability of factors of non-specific protection of the body of calves from ecologically heterogeneous areas of Orenburg region, J. of Orenburg State Univer. 9, 173-177 (2007)

16. T. Lehner, Immunology of oral diseases, 3rd ed. (Blackwell Sci. Publ., Oxford, UK, 1992) 